The Right to the Social Protection of Citizens in Conditions of the Armed Conflict in Eastern Ukraine: Legislative Challenges

Author(s): Volodymyr Venher

Source: Kyiv-Mohyla Law and Politics Journal 4 (2018): 99-118

Published by: National University of Kyiv-Mohyla Academy

http://kmlpj.ukma.edu.ua/ 


\title{
The Right to the Social Protection of Citizens in Conditions of the Armed Conflict in Eastern Ukraine: Legislative Challenges ${ }^{1}$
}

\author{
Volodymyr Venher \\ National University of Kyiv-Mohyla Academy, \\ Department of Legal Philosophy and Constitutional Law
}

\begin{abstract}
The article focuses on problematic issues of the implementation of the right to the social protection of persons who have suffered from an armed conflict in Eastern Ukraine. It presents a general analysis of the shortcomings of national legislation that limits the constitutional provisions for citizens of Ukraine to obtain the appropriate level of social protection. The article shows the problems of the status of internally displaced persons (IDPs), which should provide for them additional guarantees from the state, including social ones. However, the carried out research shows that this status often becomes a discriminatory factor that imposes disproportionate restrictions on individuals. The current legal regulation of social payments for internally displaced persons contains a number of rigid and rather complicated administrative procedures that significantly restrict, and in some cases even generally make it impossible to obtain social protection. The only effective remedy for the protection of an infringed right for pensions or other social benefits for internally displaced persons is an appeal to a court. The courts do not always carry out effective and prompt protection of the violated law. Despite positive examples of judicial practice, it can not always provide an adequate and well-timed level of social protection, which causes the need for the improvement of national legislation.
\end{abstract}

Key Words: right to social protection, internally displaced person, pension, social benefits, armed conflict, conflict in Eastern Ukraine, discrimination.

\section{Introduction}

The social protection of citizens in the conditions of the armed conflict in Eastern Ukraine is perhaps the greatest challenge for the public administration system. A modern civilized and democratic state should provide an adequate level of social protection for its citizens, even under difficult circumstances. Moreover, the condition of an ongoing 
armed conflict determines the use of additional complex and comprehensive measures for the social protection of persons who have suffered from such a conflict.

At the same time, a number of objective circumstances (the lack of effective control by the state over a part of its territory, the need for security, limited resources etc.) distract the priority of state policy from social issues. Under such conditions the legislative protection of the constitutional right to social protection in Ukraine verges on finding balance and compromise. For the proper regulation of the status of persons who have suffered from the occupation of the territory of Ukraine, a special status was introduced by law - that of an internally displaced person. The aim of this status is to ensure the consideration and implementation of special social needs of people who were forced to leave their homes. Today in Ukraine there are more than one and a half million internally displaced persons. ${ }^{2}$ This is a fairly large number of people requiring systematic and concerted actions by all public authorities to develop and implement special mechanisms for the protection of these people. Of course, the Ukrainian experience is not unique, as many countries have previously faced the need to resolve the internal displacement of a large part of the population in connection with an armed conflict. ${ }^{3}$ However, the Ukrainian case is complicated by the scale of the conflict, its duration, and socio-political preconditions that did not contribute to the readiness of the Ukrainian authorities to cope with such a situation.

In such circumstances, the issue of the social protection of citizens, like many others, receives new and non-standard solutions for the Ukrainian legal system. Thus, the constitutional right to proper social protection from the state has received new features and characteristics. Moreover, its legislative regulation and practical implementation for internally displaced persons has outlined a number of longstanding Ukrainian problems that concern the quality of normative acts and their frequent contradictions with provisions of the Constitution of Ukraine. Current national legislation, for example, on pensions and social benefits has substantially corrected the constitutional essence of corresponding human rights. Such adjustment has led to a significant limitation, and in some situations even a leveling up of the essence of human rights. It should be noted that such adjustment was carried out, as a rule, at the level of Government regulations.

Today, the available grounds and procedures for obtaining social benefits, which are defined by law, are subject to fairly harsh criticism by human rights organizations and international experts. As a result, discriminatory and disproportionate restrictions on the rights of internally displaced persons are gradually being subjected to judicial review and change. However, this process is occurring rather slowly and is not yet very effectively reflected in the prompt updating of relevant national legislation.

According to official information of the Ministry of the Social Policy of Ukraine, there are 1,517,757 internally displaced persons from the Donetsk, Luhansk and Crimea regions, who were officially registered by state authorities (as of August 13, 2018), accessed August 20, 2018, https://www.msp.gov. ua/news/15737.html. 
The above circumstances have led to the necessity of conducting research on the state of the observance of human rights and the rule of law in connection with the armed conflict in Eastern Ukraine. This article presents some of the parts and materials from in-depth research that was carried out in June-December 2017.4 The empirical basis of the above-mentioned research is a detailed examination of court practices (more than 5 oo court decisions were analyzed) in corresponding categories of cases, as well as the results of regional discussions (Kramatorsk, Mariupol, Severodonetsk, and Kherson), which covered more than 100 participants. This article reveals the peculiarities of the constitutional right to social protection on the basis of the analysis of the theoretical and legislative foundations of this right, as well as the practice of its realization. Practical examples are based on personal interviews with human rights activists, judges, and civil servants of state and local self-government bodies responsible for these issues. The characteristics of the state of the social protection of internally displaced persons presented here are based not only on provisions of legal acts, but also on numerous reports of human rights and experts organizations.

\section{The Constitutional Right to Social Protection}

The Constitution of Ukraine guarantees the right for social protection to all citizens. The scope of such protection in different situations should be established by a special law, depending on the circumstances. The Fundamental Law of Ukraine also establishes the main forms of social protection. In accordance with Article 46 , this right is guaranteed primarily through the existence of a system of obligatory state social insurance. The standard of pensions and other social security payments has been raised quite high by the state, since it is provided for that social benefits and state assistance, if they are the main sources of existence, should ensure a standard of living not lower than the subsistence minimum. ${ }^{5}$ Thus, the system of social benefits and state assistance is the main tool for ensuring social protection by the state for citizens of Ukraine.

The content and scope of the notion of the social security of citizens in the uncontrolled territories of the Donbas region and internally displaced persons on the territory of Ukraine are interpreted quite widely. Moreover, the approaches to the level (volume) and procedures for implementing social benefits differ significantly. In particular, on October 20, 2014, the Ukrainian Parliament adopted Law of Ukraine "On Ensuring the Rights and Freedoms of Internally Displaced Persons," No. 1706-VII which regulates the main aspects of the social protection of persons who suffer from the military conflict in Eastern Ukraine.

"The Rule of Law and Occupied Territories of Donbas and Crimea" (August_-December 2017, reviewed in 2018) contains research conducted within the framework of the "Local Self-Government and the Rule of Law in Ukraine" project (implemented by the The Folke Bernadotte Academy Swedish government agency for peace, security and development, funded by Sweden). Research report available in Ukrainian only.

5 Constitution of Ukraine of June 28 1996, accessed August 20, 2018, http://zakon.rada.gov.ua/ laws/show $/ 254 \% \mathrm{D}$ ○\%BA/96-\%D ○\%B 2\%D 1\%8。. 
One of the most pronounced examples of such discrimination is that, according to Article 7 of this Law, the right of IDPs for pensions and compulsory state social insurance is only guaranteed to registered persons. The law explicitly provides that only:

for the registered internally displaced person the realization of the right to employment, pensions, compulsory state social insurance ... for social services shall be performed in accordance with the legislation of Ukraine. ${ }^{6}$

Corresponding provisions have been implemented in a sufficiently detailed manner at the level of by-laws.

In accordance with paragraph 1 of the Resolution of the Cabinet of Ministers of Ukraine No. 637 of November 5, 2014 "On Social Security Payments to Internally Displaced Persons," the appointment and continued payment of pensions (monthly lifetime maintenance), lifetime state scholarships, all types of social assistance and compensation, the provision of social services, subsidies and privileges at the expense of the state budget, and funds of compulsory state social insurance for internally displaced persons are carried out at the place of registration of such persons, as confirmed by a special certificate. ${ }^{7}$ Persons who have not received the appropriate registration are not able to receive appropriate social benefits and assistance, which, as already indicated, are the main forms of social protection.

Special attention should be paid to the absence of pensions and social security for citizens residing in the uncontrolled territories of the Donetsk and Luhansk regions, in the territory of which state authorities temporarily do not exercise their powers (uncontrolled by Ukrainian authorities). In fact, there is no activity of public authorities of Ukraine in these territories. This has resulted in the termination of all payments, including pensions.

In November 2014, a formal decision was made stipulating that in the uncontrolled territories of the Donetsk and Luhansk regions payments from the state budget, Pension Fund, and other state obligatory social security funds to Ukrainian citizens in the uncontrolled territories will be made only after government control is restored in such territories. ${ }^{8}$

6 Law of Ukraine "On Ensuring the Rights and Freedoms of Internally Displaced Persons" No. 1706-VII of October 20, 2014, accessed August 20, 2018, http://zakon.rada.gov.ua/laws/ show/1706-18.

7 Resolution of the Cabinet of Ministers of Ukraine "On Social Security Payments to Internally Displaced Persons” No. 637 of November 5, 2014, accessed May 23, 2018. http://zakon.rada.gov. ua/laws/show/637-2014-\%D o\%BF\#n5.

8 Such a decision was adopted by the Cabinet of Ministers of Ukraine in Resolution "Some Issues in the Financing of Budget Institutions, the Implementation of Social Payments to the Population and Provision of Financial Support to Certain Enterprises and Organizations of the Donetsk and Luhansk Oblasts, as Well as Other Payments From Accounts Opened in Treasury 
That is, residents of the temporarily occupied territories will not be able to receive pensions and social benefits until they become internally displaced persons in the sense of national legislation and will receive a certificate of an IDP.

This legislative limitation creates a situation where Ukrainians who live in the uncontrolled territories of the Donbas region cannot enter territory controlled by Ukraine and are deprived of pensions and social security. It should be noted that accurate official statistics on the number of pensioners who are in the uncontrolled territory of the Donetsk and Luhansk regions, in particular, about those deceased and those who have emigrated, are absent.

According to a Report of the Office of the United Nations High Commissioner for Human Rights on the human rights situation in Ukraine $^{9}$ at least 160,000 pensioners residing in territory controlled by armed groups did not receive their pensions between December 2014 and December 2016.

In this situation, the issue of paying pensions is particularly critical. In Ukraine, the system of obligatory state pension insurance is still in force. The receipt of a pension in Ukraine is conditional on the mandatory pre-payment of contributions. This generates the legal nature of pension payments on the level of property rights.

Today in Ukraine, at the legislative level, the payment of pensions, which is a fundamental constitutional right, is actually combined with the payment of social assistance to IDPs. Moreover, regarding the mechanism of their payment, retirement pension and social security benefits depend on the availability of IDP status.

Given the difference in the legal nature of respective rights, this approach is rather disputable because social benefits, unlike pensions, are not a constituent fundamental human right. They are rather positive, although discretionary, obligations of the state. By the due process of law, the CMU can define conditions for such payments. As a result, the rights of citizens in uncontrolled territories and those of the IDPs should be guaranteed and exercised through different means. The application of the same mechanisms of their establishment creates a number of problems. Moreover, there is a lack of a systematic and integrated approach to understanding the social needs of internally displaced persons in Ukraine. ${ }^{10}$ According to European standards, free or forced change of residence should under no circumstances lead to the loss of the obligation of the state to its citizens' pension security.

A good example in this situation is the position of the European Court of Human Rights in the case of Pichkurv. Ukraine, which concerned the termination of the payment of a pension to a person who moved abroad. The ECHR noted that the claimant had

Bodies" No. 595 of November 7, 2014, accessed May 23, 2018, http://zakon.rada.gov.ua/laws/ show/595-2014-\%D ○\%BF.

Report on the situation of human rights of the Office of the United Nations High Commissioner for Human Rights from February 16 to May 15, 2017, accessed May 23, 2018. http://www. ohchr. org/Documents/Countries/UA/UAReport18th_UKR.pdf.

10 Tetyana Semigina, and Natalia Gusak, "Armed Conflict in Ukraine and Social Work Response to It," Social, Health, and Communication Studies Journal 2.1 (2016):1-24, accessed May 23, 2018, https://journals. macewan. ca/shcsjournal/article/view/269. 
worked in Ukraine for many years, and denying him his right to a pension, despite his contributions to the pension fund during his whole period of employment, only for the reason of a change in his place of residence, was a violation of his rights provided by Article 1 of Protocol 1 of the European Convention on Human Rights. ${ }^{11}$

Moreover, taking into account the aforementioned provisions of the legislation on the possibility of obtaining a pension only while having the status of an IDP creates additional administrative obstacles for obtaining a pension. However, requirements for the eligibility of pensions cannot depend on the place of residence of the retired and do not comply with current laws on retirement that establish the right for a pension for every eligible person.

Human rights organizations and international experts have criticized the Government's decision to link the payment of pensions, which is a constitutional right, to obtaining IDP status. Moreover, such a system of realization of the right to social protection for IDPs in fact forces people to become IDPs in order to be able to exercise their constitutional right for social security.12 Experts appropriately specify that this practice of legislative regulation can in fact be perceived as an actual compulsion to displacement, which contradicts UN Guiding Principles on Internal Displacement.

In this regard, the main problem in the context of social protection is the issue of the disproportionate limitation of human rights in connection with the implementation of the social functions of the state. The constitutional right to social protection is actually conditioned by additional legislative restrictions that do not correspond to the purposes of the state's activity. Particularly critical is the establishment of such restrictions not by law, but at the level of Government regulations.

\section{Shortcomings of Legal Regulation and Practical Problems}

Large number of by-laws are adopted in order to meet the requirements of the Law of Ukraine "On Ensuring the Rights and Freedoms of Internally Displaced Persons" regarding the restriction of the implementation of the right to social protection. National legislation provides that public authorities verify the IDP who receives social and pension benefits for the purpose of checking and obtaining necessary data on internally displaced persons.

Such verification procedures generally provide a complex set of measures to determine the relevance of the formal right to receive social benefits by internally displaced persons. These basic procedures are: the verification and monitoring of the credibility of information provided by an IDP to receive social payments, physical identification of an IDP in Oshchadbank branches, verification of the place of residence by social protection services, verification of an IDP's stay in the temporarily

11 Pichkur v. Ukraine, 10441/06 (ECHR, November 7, 2013).

12 "Universal Periodic Review: An Alternative Dimension. The Third UPR Cycle, Ukraine.

Compilation of CSOs' Alternative Reports," accessed May 23, 2018, http://hro.org.ua/files/ docs/1494932877.pdf. 
uncontrolled territory of Ukraine for over 6o days. This is not an exhaustive list as there are other procedures of inspection indirectly provided for by legislation..$^{13}$

It should be noted that such numerous and cumbersome verifications lead, to some extent, to the discrimination of IPDs and the violation of their rights for pension security, social protection, freedom of movement, and the protection of their private and family life.

Another obstacle for IDPs accessing pensions and social services is constant verification of the place of residence. On March 14, 2016, the CMU approved Resolution "On Amendments to Some Orders of the Cabinet of Minsters of Ukraine" No. 167 that changed the procedure for the registration of IDPs and the procedure for receiving social payments by them. The introduced amendments have created serious obstacles in IDP access to social protection, which is why detailed analysis of such obstacles is necessary.

Thus, cl. 3 of "The Procedure for the Preparation and Issuance of IDP Registration Certificates," approved by CMU Resolution No. 509 "On the Registration of Internally Displaced Persons" of October 1, 2014 has been enlarged. It has been specified that to register, IDPs are not allowed to use addresses of public authorities, local selfgovernment, EI, labor and social protection services, SMSU offices, district state administrations, executive offices of local councils, legal entities and their offices, and any other premises where such persons do not reside in fact. ${ }^{14}$

CMU Resolution "On Some Issues of the Payment of Social Assistance to Internally Displaced Persons" No. 365 of June 8, 2016, approved the Procedure for the awarding of social payments for internally displaced persons and the Procedure for control over the delivery of social payments to internally displaced persons to their actual place of residence/stay.

According to this Resolution, as a requirement for receiving any social payments, IDPs have to pass verification of their actual place of residence, indicated in their IDP ID, conducted by a social protection authority not less than once every six months. The IDPs absence at his/her place of residence, indicated in his/her IDP ID, can lead to his/her loss not only of social assistance/pension, but also of the IDP ID (according to cl. 9 of "The Procedure for Control Over the Delivery of Social Payments to Internally Displaced Persons to Their Actual Place of Residence/Stay.") Payments can be renewed only after two months, and if the IDP ID is canceled, after six months. ${ }^{15}$

13 These and other relevant procedures were presented by special resolutions of the Cabinet of Ministers of Ukraine (No. 5 og of October 1, 2014; No. 637 of November 5, 2014; No. 365 of June 8, 2016 and others).

14 Resolution of the Cabinet of Ministers of Ukraine "On Amendments to Certain Resolutions of the Cabinet of Ministers of Ukraine" No. 167 of March 14, 2016, accessed May 23, 2018, http:// zakon.rada.gov.ua/laws/show/167-2016-\%D ○\%BF.

15 Resolution of the Cabinet of Ministers of Ukraine "Some Issues of the Payment of Social Assistance to Internally Displaced Persons" No. 365 of June 8, 2016, accessed May 23, 2018, http://zakon.rada.gov.ua/laws/show/365-2016-\%D ○\%BF. 
International and local human rights organizations unanimously stress that these amendments considerably worsen the IDPs' situation by introducing additional discriminating mechanisms and administrative obstacles for obtaining social protection. Such novelties are critical in a situation where all types of social assistance and pensions for thousands of IDPs are canceled for up to five months. ${ }^{16}$

Cl. 3 and 4 of the Procedure for control over the delivery of social payments to internally displaced persons to their actual place of residence/stay lists a number of reasons for the additional verification of the actual place of IDPs' residence/stay, and reporting on the financial and domestic conditions of the family that can involve police, security services, State Financial Inspection, the State Migration Service of Ukraine, and the Pension Fund.

Moreover, because of such strict constant verification of IDPs at their places of residence, access to social payments and targeted financial assistance have become possible only by the decision of the Committee of state administrations or executive committees of councils after they prepare a report on an IDP's living conditions. Thus, it can be said that the decision of whether an IDP receives a pension or social payments, guaranteed by the state, actually rests with the Committees that are not established by respective laws.

It should also be noted that social protection services perform the verification or identification procedures on their own. It seems that the involvement of other local state and self-government authorities would reduce the number of obstacles in the way of the people to exercise their right for social protection.

Resolution "On Amendments to Certain Resolutions of the Cabinet of Ministers of Ukraine" No. 689 of September 13, 2017 amends the Procedure for control over the delivery of social payments to internally displaced persons to their actual place of residence/stay (CMU Resolution No. 365 of June 8, 2016) and simplifies control over social payments to certain categories of internally displaced persons. ${ }^{17}$ Verifications are cancelled for IDPs who work in public office or local self-government bodies, IDP military service members, and IDPs whose information in the Unified IDP Information Database states that they have passed PJSC Oshchadbank physical verification. The Resolution also establishes a mechanism for informing social protection services and the Ministry of Finance about the suspension of payments if physical identification fails, but it does not provide any procedures for informing on the renewal of such payments.

16 "Current State of the Rights and Freedoms of Internally Displaced Persons in Ukraine.

Stakeholders' Report. Report Prepared Within the Universal Periodic Review of United Nations

Twenty-Eighth Session of the UN Human Rights Council on Universal Periodic Review (Third

Cycle) 2017," accessed May 23, 2018, http://naiu.org.ua/wp-content/uploads/2017/10/UPR_IDP_ ukr.pdf.

17 Resolution of the Cabinet of Ministers of Ukraine "On Amendments to Certain Resolutions of the Cabinet of Ministers of Ukraine" No. 689 of September 13, 2017, accessed May 23, 2018, http://zakon.rada.gov.ua/laws/show/689-2017-\%D ○\%BF. 
Representatives of the Vostok-SOS Charity Foundation note that, because of these amendments, persons whose social payments were suspended may no longer receive them when they are renewed. This means that a person will have to personally inform the Ministry of Finance and social protection services that he/she has passed their physical verification. ${ }^{18}$

It should be noted that, despite the said potential drawbacks, such simplification of the control over social payments to certain categories of IDPs are positive and significantly improve their situation, although they do not solve the main problem. An important practical issue of a smaller scale is the possibility of obtaining social benefits exclusively to accounts in branches and ATMs of the Oshchadbank PJSC.

Amendments in CMU Resolution No. 637 of November 5, 2014 "On Social Payments to Internally Displaced Persons" provide that from July 1, 2016 all payments of pensions (monthly lifetime financial support), lifetime state allowances, all types of social assistance and compensations, and financial assistance (hereinafter, "social payments") awarded to such persons shall be performed through accounts and network of branches and ATMs of the PJSC Oshchadbank. In which case, starting August 1, 2016, IDP pensioners will receive improved security bank cards that also serve as pension IDs and can order a debit card that will also serve as a pension ID.

Also, physical identification of the bank's clients was introduced by the PJSC Oshchadbank: the first two identifications take place every six months, thereafter every 12 months. After the debit card expires, it is reissued at the bank's cost. Without such physical identification, the bank ceases debit operations on the current account.

It should be noted that public authorities and the PJSC Oshchadbank take certain measures to make these services more accessible to clients. For example, some mechanisms for the identification and verification of social payments payees and special conditions for providing services to clients with special needs have been introduced. At the same time, such simplifications do not change the general procedure for obtaining confirmation of the right to receive social benefits.

Through special Resolutions of September 13, 2017 and July 11, 2018, the Cabinet of Ministers of Ukraine introduced changes to this order, which provide internally displaced persons the possibility to receive cash funds and make electronic transactions using the network of branches and ATMs of banks only in the controlled territories. Social payments to internally displaced persons with group I disability and persons who were found by a medical consultative board as persons unable to attend to themselves and requiring constant outside help, can, following their written applications, be made by the PJSC Ukrposhta with delivery to the actual place of residence/stay of such persons. ${ }^{19}$

18 "Lawyers: 'Resolution No. 689 does not Include Some Mechanisms Allowing the Amendments to Function Completely," accessed May 23, 2018, http://voicecrimea.com.ua/main/ video/8297.html.

19 Resolution of the Cabinet of Ministers of Ukraine "On Amendments to Certain Resolutions of the Cabinet of Ministers of Ukraine" No. 548 of July 11, 2018, accessed May 23, 2018, http:// 
Thus, the results of the monitoring of IDP pensioner awareness of electronic pensioner's IDs conducted by the Pravo na zakhyst (Right to Protection) NGO showed that most IDPs complain that it is inconvenient to receive pensions at the Oshchadbank for a number of reasons, including long queues, a poor infrastructure, a lack of branches/ ATMs in their settlements, and the inability to withdraw cash at other banks. ${ }^{20}$ Thus, in their Monitoring report, the Pravo na zakhyst NGO stressess the restriction of rights to pensions by displaced pensioners, the inviolability of home and freedom of movement, and the right to trial. The NGO believe that the Government should develop and adopt clear and transparent mechanisms of social and pension services for IDPs and victims of the conflict ensuring, at the same time, equality before the law for all citizens of Ukraine.

Thus, provisions of the legislation that established the mandatory requirements for IDPs to receive their pensions and social payments at only one bank are discriminatory and create domestic inconveniences.

These and other problems together create quite serious obstacles for the proper realization of the right to the social protection of persons who have suffered as a result of the armed conflict in the East of Ukraine.

While such problems as the possibility of obtaining social benefits at only one state bank create organizational obstacles, the procedures of verification, identification, and inspections and control, in some cases result in the complete leveling of the right to social protection. In fact, non-compliance with or violation of the above mentioned legislative requirements causes the termination of pension payments and forces internally displaced persons to take judicial recourse.

\section{Judicial Protection of Violated Rights}

Sufficiently strict conditions and procedures for obtaining social benefits give rise to even more rigid mechanisms for monitoring their compliance and cause the suspension or termination of payments. Appealing to a court for challenging the illegal actions of public authorities aimed at limiting the IDPs' freedom of movement and access to social payments, as well as the renewal of the possibility to receive social payments and pensions is becoming an increasingly widespread instrument for the protection of the rights of internally displaced persons.

Unfortunately, judicial practice concerning social security benefits, in particular, monthly lodging allowance, is quiet different. The majority of the analyzed court rulings show that judges take an extremely bureaucratic stance and believe that if the registered address of a person is not on the list of settlements approved by the CMU where the government has limited or no authority, such a person cannot be eligible for such benefits.

zakon.rada.gov.ua/laws/show/548-2018-\%D ○\%BF.

“Monitoring Report on IDP Pensioner Awareness of the Electronic Pensioner's ID," accessed May 23, 2018, http://vpl.com.ua/uk/materials/zvit_za_rezultatamy_monitorynhu_ poinformovanosti_pensioneriv_vpo_pro_elektronni_pensiyni_posvidchennya/. 
At the same time, there are absolutely different rulings when judges step away from the technical limitations of laws and take into account all supporting evidence to argue their judgments and sustain the IDP status of the claimant so that such a person may exercise his/her constitutional right for pensions and other rights provided for by the law for this category of people.

Another example is that courts formally limit the payment of social assistance to IDPs without, at times, even analyzing the essence of the relevant human rights and effect of their limitation. Indeed, one of the courts in the Luhansk region sustained an appeal of an Office of Social Protection to collect the overpaid amount of social assistance to an IDP for living expenses, including housing and utilities costs, because the defendant possessed bank savings exceeding 10 minimum living wages. ${ }^{21}$ At the same time, the court did not duly analyze the fact, as seen in the ruling, that the defendant did not have any possibility to use the said savings because of the bank's problems.

Apparently, court rulings could have been different if all circumstances had been studied in more detail and an effort had been made to protect the human right for social protection despite formalities of the law. This situation could have been improved by better cooperation between public authorities (including courts), in particular, when it concerns the exchange of data, etc.

At the same time, there are absolutely different rulings when judges step away from the formal limitations of laws and take into account all supporting evidence to argue their judgments and sustain the IDP status of the claimant so that such a person may exercise his/her constitutional right for pensions and other rights provided for by the law for this category of people.

For example, one of the courts in the Donetsk region sustained a claim about the inactivity of the social protection agency that had refused to issue an IDP ID. ${ }^{22}$ Such inactivity was ruled to be unlawful and thus the agency was compelled to issue the certificate of registration to a person who had relocated from the temporarily occupied territory to the ATO zone. Such a ruling was made despite the fact that the registered address of the claimant was not in the settlement officially listed by the CMU as one where the government has temporarily limited or no authority.

At the same time, the court argued its decision on rather serious and detailed facts. In addition to constitutional provisions on the social security of persons, reference was made to much other evidence: memorandums of the NSDC, the President of Ukraine, and the CMU about the actual inability of government authorities to operate in that settlement, as well as "...daily updates of operational information (about the development of the ATO and the "Situation in Eastern Ukraine" map showing territories and settlements affected by the ATO and military actions, and liberated settlements

21 Judgement of the Makivskyi District Court in the Luhansk Region of May 5, 2017, case No. 473/3514/16-ц.

22 Judgement of the Krasnoarmiiskyi District Court in the Donetsk Region of June 17, 2015, case No. $235 / 3111 / 15^{-a}$. 
where government authorities do not function) by the Data Analysis Center of the NSDC on the NSDC's web-site. ${ }^{23}$ As of March 6, 2015, in Adviivka and Pisky, battles continue between the army and the terrorists, while Severne of the Yasynuvata district in the Donetsk region is located between these two settlements." ${ }^{24}$

An interesting and rather strange fact is that the administrative action was brought to court by a local state attorney, and 12 days before the resolution of the case another judge of the same court made a completely different judgment in an identical case. Most probably, this testifies to the lack of communication between judges of even that same court and proper control over the uniformity of litigation practices.

As a rule, in their appeals to the courts, IDPs ask to rule on the suspension of old-age pensions by the Pension Fund of Ukraine as illegal and to bind the Pension Fund of Ukraine to renew such pensions. Litigation practices show that such claims are sustainable. In such cases, the PFU takes a typical stance by claiming that the pension was canceled legally because the verification of data in the Unified Database of registered Internally Displaced Persons showed that the concerned person was no longer registered as an IDP on the date of such verification.

However, the courts often reject such evidence of public authorities, sustain opposing evidence, and hold uncorroborated the claim that the IDP does not actually live at the reported address. This actually proves that the inactivity of public authorities upsets the balance between adverse effects for exercising their rights for old-age pensions and social protection, as defined in Art. 46 of the Constitution of Ukraine, by claimants and the purpose pursued by such inactivity of the defendant public authority.

The decision of the Supreme Court on a model case of May 3, 2018, No. 805/402/18 (No. $\operatorname{Pr} / 9901 / 20 / 18$ ), concerning the appeal of the suspension of pension payments to an IDP was a significant step towards more effective judicial protection of the rights of internally displaced persons..$^{25}$ In the case, the Court originally explained that

the status of an internally displaced person grants the person special, additional rights ... without, however, limiting the scope of the constitutional rights and freedoms of the individual and creating additional guarantees for their implementation. ${ }^{26}$

23 NSDC - National Security and Defense Council of Ukraine.

24 Judgement of the Krasnoarmiyskyi District Court in the Donetsk Region of June 17, 2015, case No. 235/3111/15-a.

25 As a result of judicial reform, a new institution has been added to court appeals - the Supreme Court adopts test decisions in typical cases. In accordance with part three of Article 291 of the Code of the Administrative Justice of Ukraine, the courts must take into account legal conclusions of the Supreme Court, which are set forth in the decisions on test cases. of Pension Payments to an IDP" of May 3, 2018, No. 805/402/18 (No. Pr/99o1/20/18), accessed May 23, 2018, https://supreme.court.gov.ua/supreme/inshe/zrazkovi_spravu/zr_ rish_805_402_18. 
Based on this understanding of the status of the internally displaced person, it was established that the non-confirmation of the actual place of residence cannot be regarded as the basis provided by law for the termination of pension payment.

...by terminating the calculation and payment of the plaintiff's pension in the absence of grounds foreseen by the laws of Ukraine, the defendant violated the claimant's right to receive a pension. In this case, the right to receive a pension is the object of protection under Article 1 of Protocol 1 of the Convention for the Protection of Human Rights and Fundamental Freedoms. ${ }^{27}$

On the basis of this model decision, according to the provisions of Article 291 of the Code of Administrative Justice of Ukraine, courts have already taken quite a number of decisions in cases on the protection of the right to receive a pension or other social benefits. At least several hundred typical cases that became the basis for initiating the adoption of this model decision have the possibility for a positive outcome. At the time of the preparation of this analysis, more than a thousand court rulings can be found in the Unified State Register of Court Decisions, where arguments from the Model Supreme Court decision dated May 3, 2015, No. 805/402/18 have been used. Generally, this is a positive trend for the judicial method of protecting the social rights of internally displaced persons.

Also, appeals to courts against illegal actions, from the claimants' point of view, of public authorities aimed at limiting the IDPs' freedom of movement and access to social payments, as well as the renewal of the possibility to receive social payments and pensions have become more numerous and an effective instrument of the protection of IDPs' rights. It should be noted that the cancellation of pensions is a rather radical tool for imposing responsibility for violating administrative procedures and legal requirements.

The analysis shows that the majority of such decisions could have been avoided if there had been better cooperation between, for example, social protection services and local offices of the Pension Fund of Ukraine and other authorities. Unfortunately, it is the court that provides the most effective, although rarely the most expedient and efficient, protection against the violation of rights.

Given the above, the normative regulation of this situation should be more important. After all, despite the positive case law, the judicial protection of a violated right is rather cumbersome and difficult for ordinary citizens. ${ }^{28}$

Moreover, according to part three of Article 4 of the Law of Ukraine "On Ensuring the Rights and Freedoms of Internally Displaced Persons" No. 1058-IV, the conditions, norms, and procedures of pension provision are determined exclusively by laws on

27 Paragraph 83 of the reasoning part of the same Supreme Court's decision.

28 Kateryna Krakhmalova, "Internally Displaced Persons in Pursuit for Access to Justice: Ukraine,"

International Migration (2018), accessed August 20, 2018, https://doi.org/10.1111/imig.125oo. 
pensions. Thus, grounds for the termination of pension payments cannot be regulated by acts of the Cabinet of Ministers of Ukraine, which are by-laws. These issues should be regulated at the level of the law.

\section{Prospects of Solving the Problem by Adopting the Law}

Many experts have linked the adoption of the Law of Ukraine "On the Peculiarities of State Policy of Ensuring the State Sovereignty of Ukraine in Temporarily Occupied Territories in the Donetsk and Luhansk Oblasts" No. 2268-VIII (January 18, 2018) with the prospect of solving the main problems of the social protection of IDPs and citizens in uncontrolled territories. However, such hopes did not receive real legal implementation after the Law's official publication.

Actually, this Law additionally established in the list of basic directions of protection of the rights and freedoms of civilians in the temporarily occupied territories in the Donetsk and Luhansk regions the promotion, inter alia, of providing for social and economic needs, as well as the provision of legal and humanitarian assistance, including the involvement of international assistance, in particular the provision of medical and social services in the territories controlled by Ukraine (sub-paragraphs 4 and 5 of part one of Article 6 of the Law). ${ }^{29}$

It should be emphasized that the law does not provide specific legal mechanisms for improving the social protection of the population except for the voicing of such directions. Moreover, the cited provision regarding the provision of medical and social services in territories controlled by Ukraine practically formalizes and preserves the present state of the social protection of the population, connected with all these problems.

The urgency of the elaboration of such legal mechanisms was noted almost a year before the adoption of the that Law "On the Approval of a Plan of Measures Aimed at the Realization of Certain Principles of State Internal Policy Concerning Certain Districts of the Donetsk and Luhansk Regions, Where State Authorities Temporarily do not Exercise Their Powers." ${ }^{30}$ At the same time, the measures envisaged by this Plan with regard to the social protection of the population are not fully implemented. The reasons for this are both a rather general formulation of tasks and the necessity of legislative regulation of certain problem points.

Thus, the Verkhovna Rada is currently studying the draft law of Ukraine "On Amendments to the Law of Ukraine "On Compulsory State Pension Insurance" on the

Law of Ukraine "On the Peculiarities of the State Policy of Ensuring the State Sovereignty of Ukraine in Temporarily Occupied Territories in the Donetsk and Luhansk Oblasts" No. 2268VIII of January 18, 2018, accessed May 23, 2018, http://zakon.rada.gov.ua/laws/show/2268-19. 
Realization of a Right to a Pension for Citizens Who Live in Settlements in the Territory of Which Public Authorities Temporarily do Not Exercise Their Powers" (No. 4257 of February 17, 2016, proposed by N. V. Veselova, MP), which, if adopted, will allow the stoppage of the violation of human rights and prevent financial losses of the country from appeals of citizens to the ECHR.

This draft law proposes to pay pensions to citizens of Ukraine who live in settlements in the territory of which public authorities temporarily do not exercise their powers in part or in full, and in controlled territories of Ukraine following the procedure described by the CMU, provided they resubmit their applications for such payments before December 31 of each year. It is suggested to apply the same procedure for the payment of assistance, provided for by the Law of Ukraine "On State Social Assistance to Persons Who are not Entitled to a Pension and Disabled Persons."

It is also suggested to pay pensions and assistance, to which such persons are entitled, due for past periods (i. e. for 2014-2016) without any deadlines. At the same time, the draft law leaves unregulated the issue of assistance, provided for by the Laws of Ukraine "On State Social Assistance to Disabled Persons from Childhood and Disabled Children" and "On State Social Assistance to Families in Need."

According to a report of the UN Special Rapporteur on the human rights of internally displaced persons, prepared after visits to Ukraine, the registration system and suspension of social payments lead to another forced displacement, in particular to mass migration, and a spontaneous return into danger zones, which should be prevented, and thus the dependence of the payment of pensions and social payments at the registration of place of residence and IDP status need to be canceled. ${ }^{31}$ In view of this, it is proposed to support ideas enshrined in the draft law (No. 4257).

Also, on July 12, 2017, Members of Parliament registered a draft law on amendments to some laws of Ukraine on the right to receive pensions by separate categories of citizens (No. 6692). ${ }^{32}$

As indicated in the explanatory note to the draft law, taking into account the lack of the said provisions in laws that would set out the basis and principles of operation for the state in emergency situations, public authorities develop procedures on the level of by-laws, which often contradict the Constitution and have caused the following adverse effects:

...persons who have moved to the controlled territory, bought a home and registered their new place of residence, cannot receive pensions on general terms because of the obligation to provide paper documents, necessary to apply for a pension; 
... persons who have the right to a pension or pension payments and remain in the uncontrolled territories cannot receive them because of additional procedures, imposed by the CMU. ${ }^{33}$

This bill proposes the creation of mechanisms for guaranteeing pensions regardless of the place of residence and of the fact of internal displacement. However, the Main Scientific-Expert Department of the Verkhovna Rada of Ukraine, having studied the draft law, expressed some critical fundamental and technical comments. In particular, about the need to add to the draft law a provision that would ensure payment of pensions based on data in the electronic database of the Pension fund if the hard copy of the pension file cannot be obtained. ${ }^{34}$

It should be noted that a number of national and international human rights organizations and individual experts support the adoption of this bill. Their main argument is that the bill aims at eliminating the link between the payment of pensions and social assistance to the status and place of registration of an IDP. ${ }^{35}$

In view of the above, the probability of legal regulation of all listed issues remains unforeseeable. At the same time, instruments for strengthening the social protection of people, suggested in draft laws, are rather promising.

\section{Conclusions}

On the basis of the study, a rather complex and ambiguous situation regarding the ensuring of the constitutional right to social protection for those affected by the armed conflict in Eastern Ukraine can be observed. After all, national legislation protects primarily those who have maintained (or want to maintain) a lasting legal link to Ukraine. The legal form of such a relationship is legally defined special status, that of an internally displaced person.

The status of internally displaced persons should provide for additional guarantees from the state, including social ones. However, the carried out research proves that this status often becomes a discriminatory factor, especially for those who cannot obtain it because of objective reasons. Moreover, it imposes a number of additional obligations

Explanatory Note to the Draft Law "On Amendments to Some Laws of Ukraine on the Right to Receive Pensions by Separate Categories of Citizens" No. 6692, accessed May 23, 2018, http:// w1.c1.rada.gov.ua/pls/zweb2/webproc4_1?pf3511=62241.

Conclusion of the Main Scientific-Expert Department of the Verkhovna Rada of Ukraine to the Draft Law “On Amendments to Some Laws of Ukraine About the Right to Receive Pensions by Separate Categories of Citizens" No. 6692, accessed May 23, 2018, http://w1.c1.rada.gov.ua/pls/ zweb2/webproc4_1?pf3511=62241. 
(verification procedures, identification, etc.) on persons who have received and used appropriate benefits.

For today, the status of an internally displaced person is the key exclusive factor that results in receiving social assistance from the state. In view of this, it is worth solving the problem of the universality of the status of an IDP, its application as an identifier of the need for special social protection, pensions, social assistance, etc. In this case, IDP status should not be the exclusive factor that determines all types of social protection by the state. Changing approaches to solving the problem of pensions and the social security of persons who live in uncontrolled areas of the Donbas and do not receive IDP status and cannot/do not want to enter the territory under the control of Ukraine for the registration of the indicated payments.

An important theoretical issue is the need to elaborate new legal and organizational mechanisms for guaranteeing and implementing pensions, social insurance, and social benefits from the state. The aim is to ensure the differentiation of pensions from social assistance paid to an IDP, as well as other social benefits. Such differentiation should be made considering the deterioration of health, the degree of health loss, and other socially sensitive factors.

The current legal regulation of social payments for internally displaced persons contains a number of rigid and rather complicated administrative procedures that significantly restrict, and in some cases even make it impossible to obtain social protection. The overwhelming majority of such requirements and procedures are established by acts of the Cabinet of Ministers of Ukraine. Such a level of by-law regulation does not comply with the Constitution of Ukraine and special laws of Ukraine in the area of pensions and social protection. Appropriate procedures must be adopted by parliament and be binding by law.

The courts do not always carry out effective and prompt protection of the violated law. Despite the positive examples of judicial practice, it cannot always provide an adequate and well-timed level of social protection, which causes the need for the improvement of national legislation.

The only effective remedy for the protection of an infringed right for pensions or other social benefits for internally displaced persons is an appeal to a court. Judicial practice varies. Court decisions that clearly take a stand on the protection of human rights contrary to the requirements of formal legislation are rare. However, recently, one can notice a rather positive trend in this direction. Such shifts have become especially evident after a decision by the Supreme Court on a model case, dated May 3, 2018, concerning the termination of the payment of a pension to an internally displaced person. Nevertheless, only a judicial way of attaining an adequate level of social protection is not acceptable in a democratic society.

In view of the above, it is extremely important to formulate and adopt uniform, clear, and understandable legislative criteria for the cancellation/suspension of any type of social benefits for IDPs, especially in the case of pension provision. Such criteria should also be accompanied by proper implementation through mechanisms 
that enable a person to understand the causes of termination (suspension, temporary suspension, etc.) or the cancellation of pension or social benefits. In this case, the right to appeal must be guaranteed. The simplification, accessibility, and ubiquity of administrative and other public services for the registration of pensions and social benefits, their preservation, and the improvement of legal grounds for the termination of their calculation and/or payment should be provided. This should also include a series of information and communication activities and the organization of information and awareness raising activities and consultations on the provision of social support and social services at the place of IDP residence.

\section{Bibliography}

Basova, Iryna, "Internally Displaced Persons and Their Legal Statusю" Juridica International 26 (2017): 113-24.

Constitution of Ukraine of June 28 1996. Accessed August 20, 2018. http://zakon.rada. gov.ua/laws/show $/ 254 \% \mathrm{D} \circ \% \mathrm{BA} / 96-\% \mathrm{D} \circ \% \mathrm{~B} 2 \% \mathrm{D} 1 \% 8$ 。.

Decree of the Cabinet of Ministers of Ukraine "On the Approval of a Plan of Measures Aimed at the Realization of Certain Principles of State Internal Policy Concerning Certain Districts of the Donetsk and Luhansk Regions, Where State Authorities Temporarily do not Exercise Their Powers" No. 8-r of January 11, 2017. Accessed May 23, 2018. http://zakon2.rada.gov.ua/laws/show/8-2017-\%D 1\%80.

Draft Law "On Amendments to Some Laws of Ukraine on the Right to Receive Pensions by Separate Categories of Citizens” No. 6692. Accessed May 23, 2018. http://w1.c1. rada.gov.ua/pls/zweb2/webproc4_1?pf3511=62241.

Judgement of the Krasnoarmiyskyi District Court in the Donetsk Region of June 3, 2015 in case No. 235/3106/15-a.

Judgement of the Krasnoarmiyskyi District Court in the Donetsk Region of June 17, 2015 in case No. 235/3111/15-a.

Judgement of the Krasnoarmiyskyi District Court in the Luhansk Region of May 5, 2017 in case No. 473/3514/16-ц.

Krakhmalova, Kateryna. "Internally Displaced Persons in Pursuit for Access to Justice: Ukraine." International Migration (2018). Accessed August 20, 2018. https://doi. org/10.1111/imig.1250o.

Law of Ukraine "On Ensuring the Rights and Freedoms of Internally Displaced Persons" No. 1706-VII of October 20 2014. Accessed August 20, 2018. http://zakon.rada.gov. ua/laws/show/1706-18.

Law of Ukraine "On the Peculiarities of the State Policy of Ensuring the State Sovereignty of Ukraine in Temporarily Occupied Territories in the Donetsk and Luhansk Oblasts" No. 2268-VIII of January 18, 2018. Accessed May 23, 2018. http://zakon. rada.gov.ua/laws/show/2268-19.

"Lawyers: 'Resolution No. 689 Does Not Include some Mechanisms Allowing the Amendments to Function Completely." Accessed May 23, 2018. http://voicecrimea. com.ua/main/video/8297.html. 
“Legal News. UNHCR Representative in Ukraine." Accessed May 23, 2018. http://unhcr. org.ua/attachments/article/244/2017\%2008\%2oLegislative\%2oUpdate\%2O FINAL\%2oU\%D ○\%go.pdf.

"Monitoring Report on IDP Pensioner Awareness of the Electronic Pensioner's ID." Accessed May 23, 2018. http://vpl.com.ua/uk/materials/zvit_za_rezultatamy_ monitorynhu_poinformovanosti_pensioneriv_vpo_pro_elektronni_pensiyni_ posvidchennya/.

"Information on the Number of Officially Registered Internally Displaced Persons from the Donetsk, Luhansk and Crimea Regions (of August 13, 2018)." Accessed August 20, 2018. https://www. msp. gov. ua/news/15737.html.

Pichkurv. Ukraine 10441/o6 (ECHR November 7, 2013).

"Report of the Pension Fund of Ukraine for 2017." Accessed August 20, 2018. https:// www. pfu. gov. ua/content/uploads/2018/o4/block_o3-149_budget-2017.pdf.

"Report of the Special Rapporteur Ukraine for 2014." Accessed May 23, 2018. https:// documents-dds-ny.un.org/doc/UNDOC/GEN/G15/o70/51/PDF/G1507051.pdf? OpenElement.

"Report on the Situation of Human Rights of the Office of the United Nations High Commissioner for Human Rights from February 16 to May 15, 2017." Accessed May 23, 2018. http://www. ohchr. org/Documents/Countries/UA/UAReport18th_ UKR.pdf.

Resolution of the Cabinet of Ministers of Ukraine "On Amendments to Certain Resolutions of the Cabinet of Ministers of Ukraine" No. 167 of March 14, 2016. Accessed May 23, 2018. http://zakon.rada.gov.ua/laws/show/167-2016-\%D ○\%BF.

Resolution of the Cabinet of Ministers of Ukraine "Some Issues in the Payment of Social Assistance to Internally Displaced Persons" No. 365 of June 8, 2016. Accessed May 23, 2018. http://zakon.rada.gov.ua/laws/show/365-2016-\%D ॰\%BF.

Resolution of the Cabinet of Ministers of Ukraine "On Amendments to Certain Resolutions of the Cabinet of Ministers of Ukraine" No. 548 of July 11, 2018. Accessed May 23, 2018. http://zakon.rada.gov.ua/laws/show/548-2018-\%D ○\%BF. Resolution of the Cabinet of Ministers of Ukraine "Some Issues in the Financing of Budget Institutions, the Implementation of Social Payments to the Population, and the Provision of Financial Support to Certain Enterprises and Organizations of the Donetsk and Luhansk Oblasts, as Well as Other Payments From Accounts Opened in Treasury Bodies" No. 595 of November 7, 2014. Accessed May 23, 2018. http://zakon.rada.gov.ua/laws/show/595-2014-\%D ○\%BF.

Resolution of the Cabinet of Ministers of Ukraine "On Social Security Payments to Internally Displaced Persons” No. 637 of November 5, 2014. Accessed May 23, 2018. http://zakon.rada.gov.ua/laws/show/637-2014-\%D ○\%BF\#n5.

Semigina, Tetyana, and Natalia Gusak. "Armed Conflict in Ukraine and Social Work Response to It." Social, Health, and Communication Studies Journal 2.1 (2016): 1-24. Accessed May 23, 2018. https://journals. macewan. ca/shcsjournal/article/ view/269. 
Decision of the Supreme Court on a Test Case "Concerning an Appeal of the Suspension of Pension Payments for an IDP” of May 3 2018, No. 805/402/18 (No. Pr/9901/20/18). Accessed May 23, 2018. https://supreme.court.gov.ua/supreme/inshe/zrazkovi_ spravu/zr_rish_805_402_18.

"Universal Periodic Review: An Alternative Dimension. The Third UPR Cycle, Ukraine. Compilation of CSOs' Alternative Reports." Accessed May 23, 2018. http://hro.org. ua/files/docs/1494932877.pdf.

Volodymyr Venher is an Associate Professor at the Faculty of Law, National University of Kyiv-Mohyla Academy. He received his $\mathrm{PhD}$ in Constitutional Law from the National University of Kyiv-Mohyla Academy and Legislation Institute of Verkhovna Rada of Ukraine. He specializes in constitutional law, election law, and human rights. 